\title{
統計的手法に基づくワイヤロープの曲げ疲労寿命予測*
}

\author{
佐々木 康二*1 岩 倉 昭 太*1, 高 橋 龍 彦*2 \\ 守谷敏 $之^{* 3}$ 古川一平*3
}

\section{Estimating Fatigue Life of Wire Rope with Stochastic Approach}

\author{
Koji SASAKI*4, Shota IWAKURA, Tatsuhiko TAKAHASHI, \\ Toshiyuki MORIYA and Ippei FURUKAWA \\ ${ }^{* 4}$ Mechanical Engineering Research Laboratory, Hitachi Ltd., \\ 502 Kandatsu, Tsuchiura, Ibaraki, 300-0013 Japan
}

\begin{abstract}
We propose a new method of estimating the fatigue life of wire ropes of elevator. It is based on the assumption that the life of wire rope is determined by the fretting fatigue life of wires. Estimates done on a sample wire rope with the method were in good agreement with the experimental results. The method of estimation involves four steps. First, we did a finite element analysis and estimated the pressure between the wires. To take into account the behavior of the whole wire rope and each wire in the stress analysis, we did a zooming analysis. Second, we conducted a fretting fatigue test on the wires to construct a fretting fatigue database for them. Third, we estimated the life of each wire derived from the pressures between the wires and the fretting fatigue database. Last, we estimated the life of the wire ropes derived from the life of individual wires. The rope life estimated with our new method revealed some important findings. We found that: (1) the inner wires broke earlier than the outer wires and: (2) the residual strength of the wire ropes decreased rapidly after their strength became lower than $80 \%$ of their initial strength.
\end{abstract}

Key Words: Finite Element Method, Structural Analysis, Computational Mechanics, Zooming Analysis, Fretting, Fatigue, Life Prediction, Wire Rope, Elevator

\section{1. 啨票}

エレベータ等の動索として使用されるワイヤロープ (以下，ロープと略称する)は，図 1 に示すように，エレ・ ベータの乗りかご及びカウンターウェイトによって張力 を受けながら，シーブやプーリを通過する毎に繰返し曲 げを受ける. このためロープを構成する素線はシーブや プーリとの接触により摩耗を受けながら繰返し曲げによ つて疲労破壊する. 䋊維を撚り合せた心に，複数の撚り 線（ストランド）が撚り合せられた構造のロープを用い た場合，一般にはロープがシーブやプーリに接触する部 分の素線が最初に摩耗し, 疲労破断に至る(1)ことから, ロープとシーブの間の摩耗による素線破断に着目した

* 原稿受付 2004 年 10 月 6 日。

*1 正員, (株) 日立製作所機械研究所 (300-0013 土浦市神立 町 502).

*2 正員, (株) 日立製作所水戸ビルシステム本部( $\boldsymbol{E} 312-8506$ ひたちなか市市毛 1070)

*3 東京製綱 (株) 技術本部研究所 ( 300-0195 茨城県新治郡霞 ヶ浦町宾倉 5707)

E-mail : ksasaki@merl.hitachi.co.jp
種々の寿命予測実験式が提案されている(2)(3). しかし， シーブ材質が素線材質に比べ極端に軟質な場合や，繊 維心ではなく IWRC(Independent Wire Rope Core : 独立し たロープ心)を使用した場合などの条件下では，素線 同士が摖れ合いながら曲げ応力を受けることによるフ レッティング疲労破壊がロープ寿命を支配する事例が

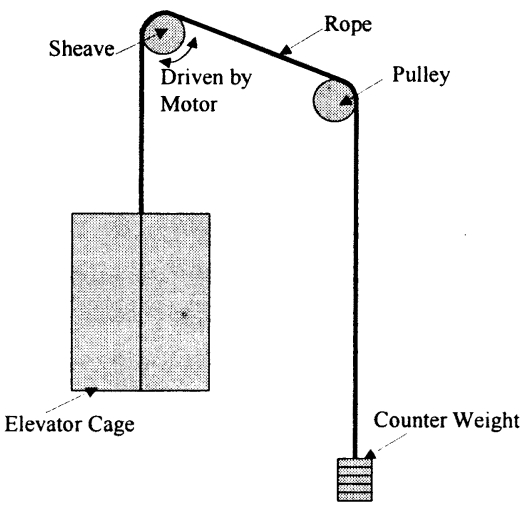

Fig. 1 Schematic View of Elevator 


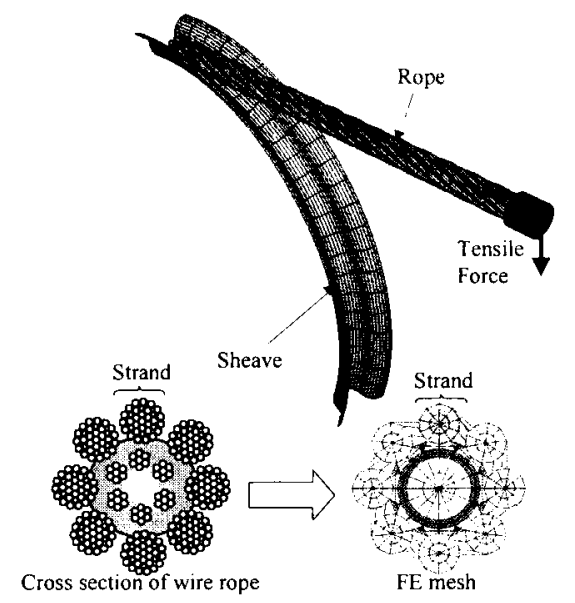

Fig. 2 FE mesh for whole-model-analysis

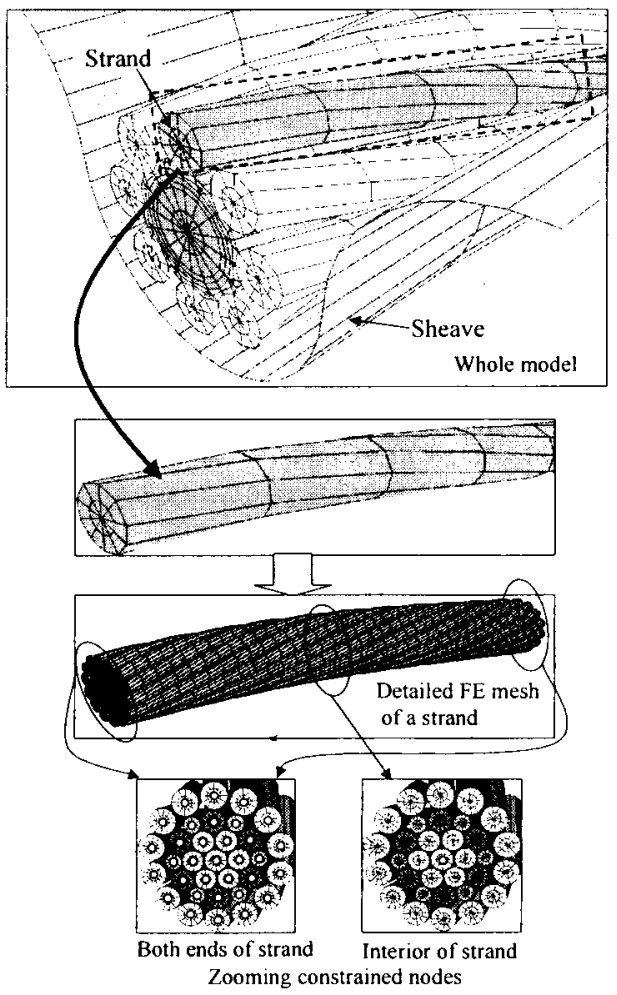

Fig. 3 FE mesh for detailed-model-analysis

報告されている(4)、ロープのフレッティングによる破 断については多くの研究がなされており，フレッティ ングに及ぼす諸因子の影響が明らかにされつつある(5) (6). しかし，フレッティングによる素線断線をべー スとし，素線強度のばらつきを考虑したロープの疲労 寿命推定に関する研究は少ない，本報告では，有限要 素法によって素線同士の接触荷重を推定し, 別途作成
したフレッティング寿命データベースと合せて素線敏 の寿命を評価し，素線の強度ばらつきを考虑して統計 的な処理を行うことにより，ロープのフレッティング 寿命を推定する方法について述べる.

\section{2. 応力解析}

\section{$2 \cdot 1$ 全体解析によるロープ曲げ变形推定}

ロープは鋼素線を数十本〜数百本撚り合せた構造で あり，通常の有限要素法によりモデル化すると解析メッ シュ数が大きくなり，計算時間や記憶頒域などの計算機 資源が膨大になり実用上解析できなくなる問題がある. そこで本報告では， ロープを構成するストランドを簡略 化した構造による全体解析と，特定のストランドを取り 出して素線レベルまでモデル化した構造による詳細解析 を組み合せたズーミング解析を実施した。

全体解析に用いた解析メッシュを図 2 に示寸，全体 解析に执いてはストランドの内部は均質な連続体でモ デル化することにより解析規模を低減している，スト ランドのヤング率は，ストランド単体の引張風性の測 定結果から 80GPa とした．また，ロープとシーブの間 には接触条件を設け，ロープに張力を与えながらシー ブに沿って曲げている.ロープの変形は非常に大きく， 微小変形の仮定が成立しないと推定されることから， 大変形応力解析条件を設定している。応力解析には HKS 社製の隍解法静的応力解析ソフト ABAQUS Ver.6.2使用した.

\section{$2 \cdot 2$ 詳細解析による素線間面圧推定}

詳細解析に用いた解析メッシュを园 3 に示寸。詳細解 析では, 1 本のストランドのみを取り出して, 素線レべ ルまで詳細にモデル化している．先に実施したロープの 全体解析の結果からストランドの変形を取り出し，変位 境界条件として詳紐解析モデルに付与することで詳細解 析を実施している．また，素線同士はロープ長手方向に 自由に滑っているとの仮定に基づき，変位境界条件を付 与する節点は，ストランドの雨端部の節点と，それ以外 のストランド中心部の節点とした. 素線同士には全て接 触条件を与えており，大変形条件での応力解析を実施し ている. 素線間のすべりを良くするために素線には表面 処理を施していることから，素線間の摩徖保数は小さい と考え，また，詳細解析結果から評価寸る素線閒の接触 面圧には，摩擦係数の影響が小さいと考えたことから， 応力解析時の接触部の摩擦係数は 0 としている. 接触面 が非常に多いことから，詳細解析には収束性の高い LSTC 社製の陽解法動的応力解析ソフト LS-DYNA Ver.9.6を使用した.

ズーミング応力解析によって得られた素線同士の接触 


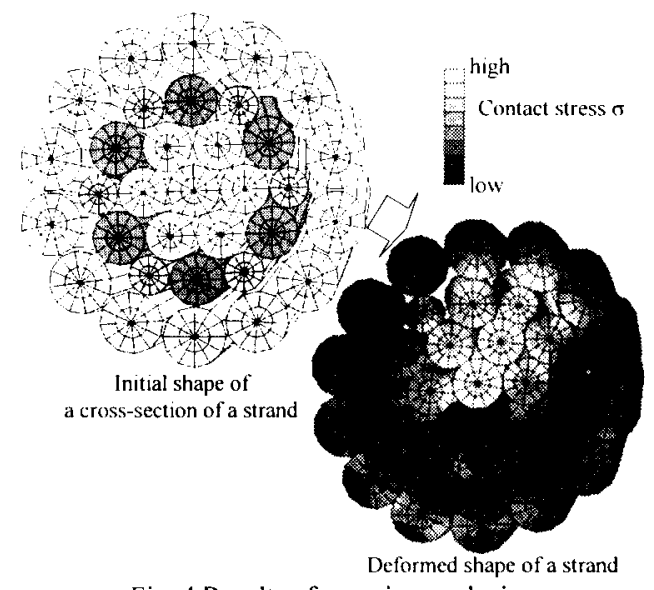

Fig. 4 Results of zooming analysis

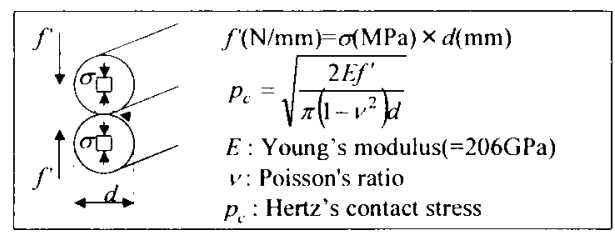

(a)Stress analysis (between parallel wires)

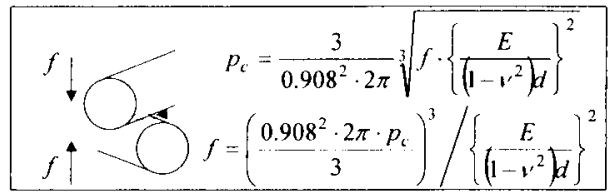

(b)Fretting fatigue test (between orthogonal wires)

Fig. 5 Calculation of contact force between wires

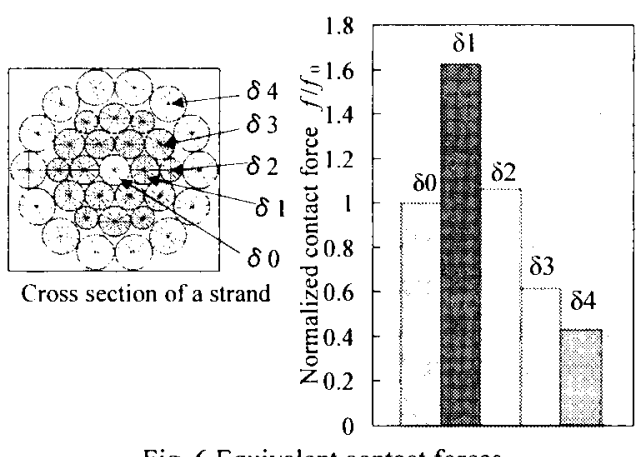

Fig. 6 Equivalent contact forces between orthogonal wires

に上万応力の分布図を，素線の変形図と合せて図4 亿示 す、ロープが引張りと曲げを受けることによりロープは 絞られながら曲げられ，結果として素線间に接触心力が 発生していることが分かる，素線同の接触言小はストラ ンドの快付近ほど高くなっている。これは，ストラン ドが絞られることにより，内側の素線ほど高い挧付け力 を受けることが原因だと若えられる。

次章で作成寸る惄線のフレッティング寿价データベー
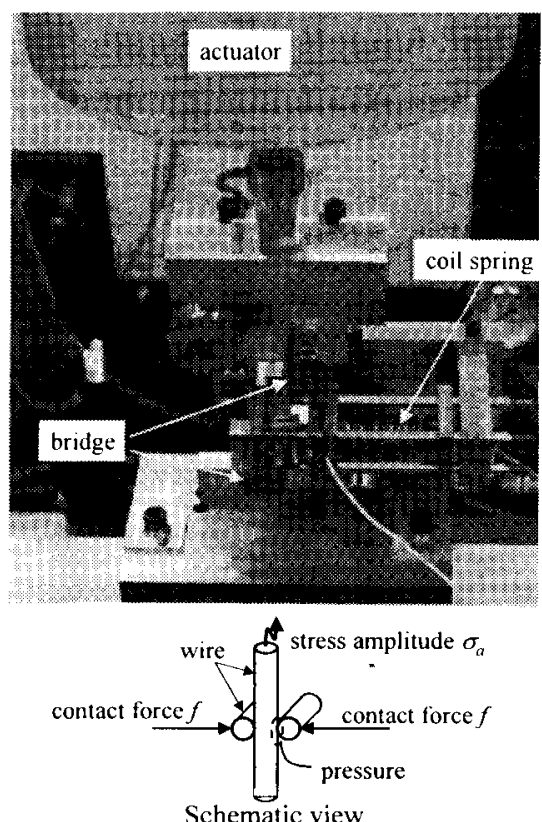

Fig. 7 Fretting fatigue test device

ス上対比して素緗の寿命予測を実施するために，ズー ミング㐫力解析によって得られた素線同士の接触によ る応力を, 直交素線の接触荷重に変換した。

図 5 に変換方法を示寸。ここでは，态力解析で得られ た平行素線間の接触による Hertz 応力と, フレッティ ング試験で実施する直交素線の接触による Hertz心応力が 等しいとした条件で接触荷重を求めている.この計算か ら得られた各層䕀線の接触荷重を図 6 に示寸，同図より， 第 1 層素線 $(\delta 1)$ )接触荷重が大きいことが分かる。この ことから， $\delta 1$ 素線のフレッティング寿命は他の素線に 比べて短くなることが予想される.

\section{3. フレッティング度労試験}

\section{$3 \cdot 1$ 試験方法}

前章で実施したロープの応力解析で得られた素線同 士の接触荷重及びワイヤロープ理論式により求められる 素線曲げ応力㽖ら素線のフレッティング疲労寿命を推 定することを目的として，素線の断線寿命を求めるフレ ッティング波労試験を実施した. フレッティンク訊験装 置を図 7 に示寸，フレッティンク訪鈋装置は，加振機之 押付荷重を付与寸るコイルばねかからなる扣振譏によって

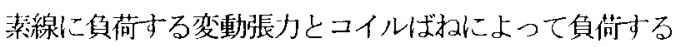
掤付葆重はロードセルで計測した。素線间士が接触した 状態で押付荷重と繰返し引張荷重を付与した。素線の座 话を避けるため, 素線の变動荷重は引張りの片振りとし ている．押付何重及ひ㐫力报幅を複数条件に変化させて， 


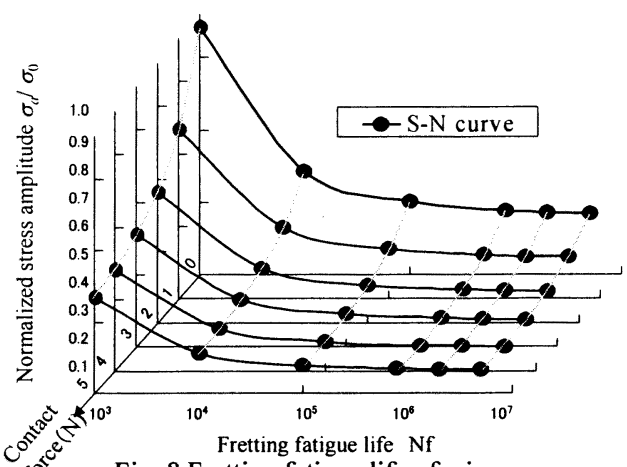

Fig. 8 Fretting fatigue life of wire

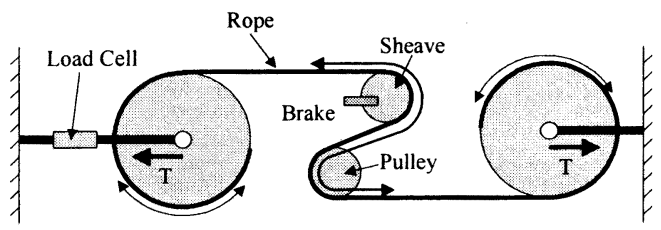

Fig. 9 Schematic View of Fatigue Test of Wire Rope

応力振幅，押付荷重と素線寿命の関係を測定した.

\section{$3 \cdot 2$ 試験結果}

フレッティング疲労試験によって得られた素線のフ レッティング寿命と素線同士の接触荷重, 応力振幅と の関係を図 8 に示す. 同図の縦軸は応力振幅を表し, 横軸は疲労寿命を表す．また，奥行き方向軸は，素線 同士の押付荷重を表す．押付荷重 0 となる一番奥側の グラフは, 通常の素線の引張疲労試験による S-N 線図 となる. 同図より，以下のことが明らかになった。

（1）いずれの押付荷重においても，応力振幅が大きく なるとフレッティング疲労寿命が小さくなる関係 がある。

（2）同じ応力振幅に対しては，押付荷重が大きいほど フレッティング疲学寿命が小さくなる.

（3）押付荷重が大きくなるにつれてフレッティング疲 労寿命一の応力振幅の影響が小さくなり，いわゆ る疲労限が存在する.

以上より，素線同士の接触荷重及び応力振幅をパラメ 一タとして，素線のフレッティング寿命が推定できるこ とが分かった.この試験結果を素線のフレッティング強 度データベースとし，次章で害施するロープの寿命予測 を行った.

\section{4. ロープの曲げ疲労寿命推定}

ロープの忘力解析結果及び素線のフレッティング疲 労試験結果から，ロープの繰返し曲げに対する寿命を推 定し，ロープの繰返し曲け試験結果と比較した.ロープ の繰返し曲け試験方法を図 9 に示寸，ロープはブレーキ
をつけたシーブ及びプーリを通り，両端を径の大きなシ 一ブで巻き取っている. ロープに引張りを与えながら両 端のシーブが往復回転することによってロープは移動し ながらシ一ブ及びプーリを通過し，繰返し曲げを受ける. また，ロープにはブレ一キ付のシ一ブを通じてトラクシ ヨン（けん引力）も負荷される.

寿命推定の際は，以下の仮定を置いている.

A) ロープの素線破断は，シーブの接触による摩耗や 疲労ではなく, 素線のフレッティング疲労によっ て生じる.

B) 調質された金属の疲労強度(疲労限)が正規分布 し，その標準偏差は $8 \%$ である ${ }^{(10)} こ$ とから，ロープ の各素線のフレッティング疲労強度(疲労限)も標 準偏差 $8 \%$ の正規分布とする.

C) 素線の初期の接触荷重, トラクションによる応力 振幅及びロープ張力による素線の引張平均応力は 有限要素法によるズーミング応力解析によって求 め, 曲げ疲労試験中のこれらの值は素線が破断す るにしたがってロープの残存断面積に反比例して 增大する.

D) 素線の破断によって変動するのは素線間の接触荷 重, トラクションによる応力振幅及びロープ張力 による素線の平均応力のみであり，その他の影響 (断面崩れなど) は無視する.

E) 素線の破断は全てロープの同一断面で発生し, 素 線の長手方向の強度ばらつきは無視する.

F) 素線はフレッティング疲労寿命に達した時点で破 断するものとし，それ以前に摩耗によって断面積 が減少するなどの影響は無視する.

ロープ曲げ寿命推定アルゴリズムを図 10 に示す.ア ルゴリズムは以下の5つのステップからなる.

I. ズーミング応力解析により, ロープ曲げ疲労試験 時の初期（ロープの素線に断線がない状態）の各 素線の曲げ応力と接触荷重を求める.

II. ロープ内の破断していない全ての素線のフレッテ イング余寿命 $N_{f}$ を求める. 余寿命は素線の曲げ応 力 $\sigma_{b}$, 張力による引張応力 $\sigma_{t}, \quad$ トラクションによる 引張応力変動 $\sigma_{i n}$ 素線間の接触荷重 $f$ 及び式(4)で

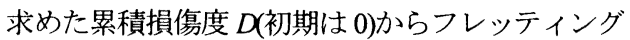
寿命データベースを用いて求める.ここでB)の仮 定により, 各素線のフレッティング疲労強度は正 規分布に則ったばらつきがあるとする。 また，C) の仮定により, 引張応力とトラクションによる引 張応力変動, 素線間接触荷重はロープの残存断面 積に反比例して増大するとする．なお，ロープの 曲げ時には素線に引張応力（平均応力）と曲げ応 
力及びトラクションによる変動応力 (応力振幅)

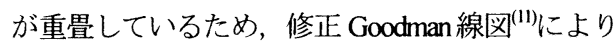
平均応力の影響を考慮している.

$$
N_{f_{t}}=(1-D) \cdot N\left(\sigma_{b}, \sigma_{t}, \sigma_{t r}, f\right)
$$

III. 全ての素線の中で最も早く破断するものを求め, 寿命 $N_{f}$ でその素線のみ破断したとして, 健全な素 線の断面積比からこの時点での残存強度 $F$ を求め る.

$$
\begin{aligned}
& N_{f}=N_{f 0}+N_{f \text { min }} \\
& F=F_{0} \cdot \frac{A}{A_{0}}
\end{aligned}
$$

ここで, $N_{\text {p }}$ は一つ前の素線が破断した時の曲げ回 数であり, $N_{\text {fin }}$ は式(1)で求めた $N_{f}$ のうちの最小值 である. また, $F_{0}$ はロープの初期強度, $A_{0}$ はロー プの初期の素線断面積合計, $A$ は破断した素線を 除いた素線断面積合計である.

IV. 全ての未破断の素線について, Miner 則 ${ }^{(11)}$ から疲労 損傷度を求める. 疲労損傷度はステップ III で破断 した素線の寿命を, 式(1)で求めたそれぞれの素線 の寿命で割ったものの累積值となる.

$$
D_{i}=D_{i 0}+\frac{N_{f \mathrm{~min}}}{N_{f i}}
$$

ここで $D_{0}$ は 1 本前の素線が破断した時点での, 各 素線の累積損傷度を表す。

V. ステップIに戻り，全ての素線が破断するまで繰 り返す。

本手法によるロープ曲け試験時の寿命推定結果を実験 結果と合せて図 11 に示す．同図の横軸はロープの曲げ 回数，縦軸は，初期を $100 \%$ とした時のロープの残存強 度を表す。ロープの残存強度は，初期の $80 \%$ 程度までは ゆるやかに低减し，それ以降は急激に全破断に至ってい る. ロープ残存強度が低下するにつれて, 素線の引張応 力, トラクションによる引張応力変動, 素線間接触荷重 が増大するためフレッティング寿命が低下することが原 因である. 比較のために実施したロープ繰返し曲け試験 では，ロープが全破断に至る前に試験を停止し，ロープ を分解して内部の素線破断状況を調査し，健全な素線の 残存状況からロープの残存強度を推定した. 実験結果か ら得られたロープの残存強度は推定結果に比べてやや高 いものの，推定結果は実験結果とよく一致し，本開発手

\begin{tabular}{|c|c|c|c|}
\hline \multicolumn{4}{|l|}{ START } \\
\hline \multicolumn{4}{|c|}{$\begin{array}{l}\text { Estimate bending stresses and pressure forces between } \\
\text { wires by zooming FEM }\end{array}$} \\
\hline \multicolumn{4}{|c|}{$\begin{array}{l}\text { Set initial rope strength } \\
\text { Set initial damage to } 0\end{array}$} \\
\hline \multirow[t]{6}{*}{$\begin{array}{l}\text { Repeat until } \\
\text { all wires break }\end{array}$} & \multicolumn{3}{|c|}{$\begin{array}{l}\text { Calculate } \\
\text { (bending stress } \\
\text { is constant) }\end{array}\left\{\begin{array}{l}\text { tensile stress of wires } \\
\text { stress amplitude caused } \\
\text { by traction } \\
\text { pressures between wires }\end{array}\right.$} \\
\hline & all wires & & $\begin{array}{l}\text { ulate remaining life from } \\
\text { ng life database }\end{array}$ \\
\hline & \multicolumn{3}{|c|}{ Weakest wire breaks(remaining life $\mathrm{dN}$ ) } \\
\hline & \multicolumn{2}{|c|}{ Surviving wires } & \multirow{2}{*}{$\begin{array}{l}\text { Calculate cumulative } \\
\text { damages of wires } \\
\text { (Miner's rule) }\end{array}$} \\
\hline & & & \\
\hline & \multicolumn{3}{|c|}{$\begin{array}{l}\text { Subtract area of a broken wire from } \\
\text { remaining area } \\
\text { Decrease rope strength proportion to } \\
\text { remaining area }\end{array}$} \\
\hline
\end{tabular}
法によってロープの寿命評価が可能であることが確認で きた. 推定結果が実験結果よりも残存強度が低い理由と しては，素線間の接触面圧を素線種類毎に一定とし，素
END

Fig. 10 Problem Analysis Diagram(PAD) of wire rope life estimation

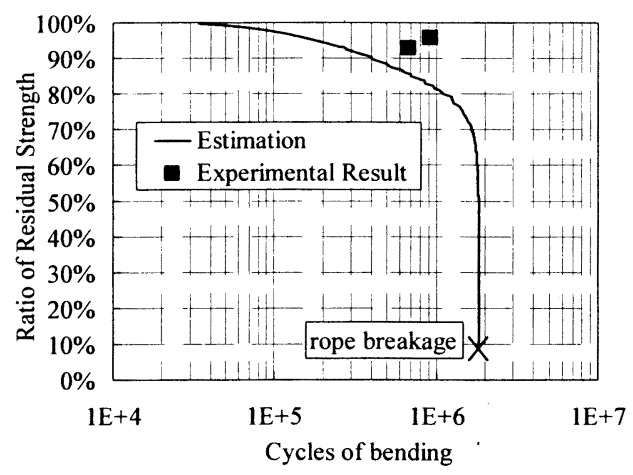

Fig. 11 Fatigue Life of Wire Rope

線毎に接触面圧の低いものがあることを無視しているこ と，素線がすべて同一断面で破断するとして，ロープ長 手方向の素線の強度ばらつきを無視していることなどが 考えられる.

本手法によって推定したロープ素線の破断状況を図 12 に示す. 同図の横軸はロープの曲げ回数を表し, 縦 軸は素線種類毎の破断素線比率を表す. 図より，ストラ ンドの第 1 層素線 $\delta 1$ の破断素線比率が早期に上昇して いることが分かる.これは， $\delta 1$ 素線が他の素線に先行 して破断していることを表す．素線の破断は $\delta 1 \rightarrow \delta 0 \rightarrow$ $\delta 4$ の順に進行し，他の素線は最終破断の直前までほと んと破断していない事がわかる.この推定結果と比較す るために疲労試験後のロープを分解調査し， $\delta 1$ 素線及 び $\delta 0$ 素線が先行破断していることを確認した. $\delta 1$ 素 線及び $\delta 0$ 素線が先行して破断するのは，ズーミング応 


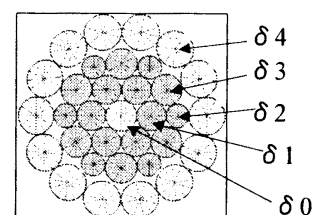

Cross section of a strand

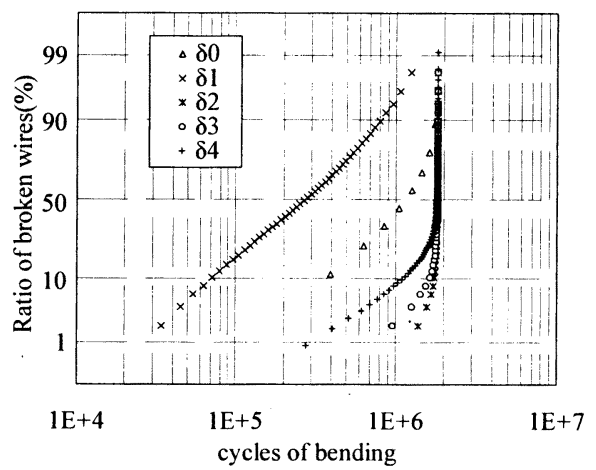

Fig. 12 Ratio of broken wires of Wire Rope

力解析から明らかになったようにこれらの素線の接触荷 重が高いことが原因である.

\section{5. 結言}

ロープの曲げ時の応力状態を求めるズーミング応力解 析手法, 素線のフレッティング強度測定手法と, これらを組 み合せてロープの曲げ疲労寿命を推定する手法を開発し た.この手法はロープ素線のフレッティング疲労寿命のば らつきを考慮して, 正規分布のばらつきを仮定している. 本 手法をロープの寿命推定に適用し, 以下の結論を得た.

（1）ロープの使用時にストランド内部に発生する接触荷重 は, 内層素線の方が高くなる傾向がある.

（2）ズーミング応力解析とフレッティング強度データベー スによる寿命推定結果は実験結果とよく一致し, 本手 法が有効であることを確認した。
(3) ロープの繰返し曲げの際には, ストランドの内層素線 が外層素線に先行して破断するという推定結果が得 られ, 実験結果と傾向が一致した。

\section{文献}

（1）菊池正晃 - 矢野利行 - 中川俊明・海田勇一郎・栗原洋，ワイ ヤロープの摩耗と疲労による寿命の評価, 日本機械学会全国 大会講演論文集 VOL. 71* Vol. B, pp365-367 (1993)

（2）松田靖, 電気機器・材料の耐久性について IXエレベータ用ワ イヤロープ, 電気設備学会誌 Vol 5No. 2pp.65-70(1985)

（3）本田武信，エレベータ用巻き上げロープの曲げ疲労特性，資 源・素材 Vol 1988 No. Mpp. 25-28(1988)

(4) T. W. Thorpe and Andrew Rance, AERE Harwell, The Tensile Fatigue of Wire Rope: ANew Approach, Proc. Of Annual Offshore Technology Conferenœ Vol. 15, No. 3, pp 483-490 (1983)

（5）田中正清, 吊上げ用具類の新検查技術に関する研究 クレー ン用ワイヤロープの疲労損傷を中心に 7 結論, 産業安全研 究所特別研究報告 NIIS-SRR， No. 18pp. 51-54(1999)

(6) Waterhouse R B, Fretting in Steel Ropes and Cables A Review, ASTM Special Technical Publication No. 1425 pp. 3-14 (2003)

（7）䨩内良雄，S. Ganesh Sundara Raman, Muthuswamy Kanaraj, 吊上げ用具類の新検查技術に関する研究 クレーン用ワイヤ ロープの疲労損傷を中心に 5 ワイヤロープ用鋼及びSNC439 鋼のフレッティング疲労挙動, 産業安全研究所特別研究報告 No. 18,pp. 35-43(1999)

（8）日本機械学会編，機械工学便覧 A4 材料力学, p109(1984)

(9) George A Costello, Theory of Wire Rope, $2 \times 1$ Edition, Springer (1997)

（10）日本材料学会編，金属材料疲労設計便覧，p15(1978)

（11）日本機械学会編，機械工学便覧 A4 材料力学, pp121-122 (1984) 